\title{
Spatial-Temporal Analysis of Solar Radiation Exposure and COVID-19 Cases in Jakarta 2020
}

\author{
Yoerdy Agusmal Saputra1, Dewi Susanna ${ }^{2 *}$
}

${ }^{1}$ Postgraduate Student, Faculty of Public Health, Universitas Indonesia, Depok, Indonesia

2Department of Environmental Health, Faculty of Public Health, Universitas Indonesia, Depok, Indonesia

\begin{abstract}
To date, coronavirus disease 2019 (COVID-19) is still a threat to public health systems around the world. As of July 25, 2021, the numbers were still increasing in most countries, and the total confirmed cases reached 194,582,750 with 4,171,672 deaths (CFR 2.1\%). In Indonesia, 3,166,505 cases were reported with 83,279 deaths (CFR $2.7 \%$ ) in all provinces and dominated by cases from Jakarta. Therefore, this study aimed to find a correlation and the duration of solar radiation exposure spatially on the pattern of COVID-19 cases. An ecological design was used based on time and place with the integration of geographic information systems and statistical techniques. The correlation test results between solar radiation exposure and COVID-19 cases in Jakarta showed a significant relationship $(p=0.000)$ with a strong closeness and positive pattern $(r=0.666)$. Furthermore, the spatial map overlaying solar radiation exposure and COVID-19 cases showed urban villages with high radiation tend to increase in cases earlier than areas with moderate and low. The differences in geographical and temporal conditions are a concern for the Provincial Health Office. This can be a consideration in strengthening more specific prevention and control programs according to the risk level and characteristics of each region.
\end{abstract}

Keywords: COVID-19, solar radiation exposure, spatial-temporal

\section{Introduction}

Until now, COVID-19 is still a threat to public health systems around the world. ${ }^{1}$ As of July 25,2021 , the numbers were still increasing, reaching 194,582,750 confirmed cases with 4,171,672 deaths (CFR 2.1\%) in 222 countries. $^{2}$ In Indonesia, the first confirmed case was reported on March 2, 2020, then increased rapidly and spread throughout the region. ${ }^{1}$ As of July 25,2021 , the reported positive cases were $3,166,505$ with 83,279 deaths (CFR 2.7\%) from all provinces dominated by Jakarta (786,882 cases), West Java (563,768 cases), and Central Java (348,675 cases). Through this relatively high number, Indonesia ranked 14, eclipsing China as the original country of this disease and was the highest in Southeast Asia. 2,3

Climatic factors such as solar radiation exposure (Ultraviolet light) are thought to affect the viability of the SARS-CoV-2. ${ }^{4}$ The sun emits light that naturally contains Ultraviolet (UV) light, but some are absorbed by the ozone layer and water vapor in the atmosphere, hence, only a small portion reaches the earth's surface.4,5 The UV lights reaching the earth's surface still have harmful effects on viruses and other microorganisms. ${ }^{4}$ Sloan et al. (2021) showed the survival of SARS-CoV-2 decreased significantly and rapidly when exposed to solar radiation exposure. ${ }^{6}$ A study in the United Kingdom showed higher exposure to UV lights in spring 2020 increased viral inactivation potential outdoors. ${ }^{7}$

The effect of solar radiation exposure on SARSCoV-2 was proven by Ratnesar-Sumate et al. $(2020)^{8}$, that simulated radiation exposure rapidly inactivated the virus suspended in either saliva or culture media and dried with stainless steel coupons. Furthermore, as much as $90 \%$ of infectious viruses were inactivated every 6.8 mins in simulated saliva and every $14.3 \mathrm{mins}$ in culture media when exposed to simulated solar radiation exposure representing the summer solstice at $40^{\circ}$ North Latitude at sea level on the same bright day. Significant inactivation also occurs, albeit at a slower rate, under lower simulated radiation exposure levels. The study provided the first evidence that solar radiation exposure rapidly inactivates SARS-CoV-2 on surfaces. Also, it showed that persistence and subsequently the risk of exposure can vary significantly between indoor and outdoor environments. Besides, these data suggested that natural solar radiation exposure is effective as a disinfectant for contaminated

Received : July 23, 2021

Accepted : July 26, 2021

Published: July 31, 2021 
Regional environmental problems are not the same between regions, therefore a spatial approach is needed in the development of environmental health. This approach describes the relationship between an incident phenomenon and all objects existing on the earth's surface with a relationship with each other. ${ }^{9}$ Therefore, this study aimed to determine the correlation patterns and spatial relationships of solar radiation exposure to the pattern of cases in Jakarta. It can then be used as consideration for formulating programs or policies regarding COVID-19 prevention and control.

\section{Method}

This study used a quantitative method with an ecological design based on time and place that is descriptive observational with the integration of geographic information systems and statistical techniques. The population was weekly data of COVID19 cases recorded at the Jakarta Provincial Health Office from March to September 2020. In this study, all population members were sampled (total sampling). Besides, daily solar radiation exposure data in Jakarta Province were also collected and converted into weekly data for seven months (March-September 2020). The timing was due to the limited availability of data at the study time. The location covered the entire Jakarta Province consisting of 267 urban villages.

The secondary data were obtained from several related agencies for the period March-September 2020. This consisted of data on COVID-19 cases obtained from the Jakarta Provincial Health Office and solar radiation exposure data were accessed online through the Meteorological, Cilmatology, and Geophysical Agency/ Badan Meteorologi, Klimatologi, dan Geofisika (BMKG) website at https://dataonline.bmkg.go.id/home. Furthermore, the basic map of Jakarta with urban village boundaries was downloaded directly from the GADM (Global Administrative Areas) Maps and Data website at https://gadm.org/. Also, were accessed online via https://www.gps-latitudelongitude.com/.

Bivariate analysis with a correlation test was carried out to determine the relationship between the independent and dependent variables using SPSS 21 software. In addition, spatial analysis was carried out to determine the relationship pattern between two variables using the QGIS 3.0 program.

\section{Results}

The average solar radiation exposure from March to September 2020 tended to fluctuate, which ranges from 3.29 to 7.66 hours per week. This tended to increase from March and reached its peak in August and September. Meanwhile, the highest average from March-September 2020 period occurred in the 26th week of 7.66 hours and the lowest average occurred in the 9th week of 3.29 hours.

\section{Statistical Analysis on Relationship}

Statistical analysis of the relationship was performed using the Pearson moment correlation test. The analysis was used to state the relationship $(p<0.05)$, closeness $(\mathrm{r})$, and direction (positive/direct or negative/opposite direction). In addition, the data were processed during March-September 2020.

The correlation test results showed a significant relationship $(\mathrm{p}=0.000)$ with a strong and positive pattern $(r=0.666)$. This means the higher the solar radiation exposure, the more COVID-19 cases, and vice versa.

\section{Graphical/ Time Trend Analysis on Relationship}

In Figure 1, it appears that the duration of solar radiation exposure tends to show a pattern in the same direction as the COVID-19 case. The opposite pattern in the duration of radiation exposure with the cases occurred at weeks 3, 6-8, 11, 16, 19, 23, 24, and 27-29.

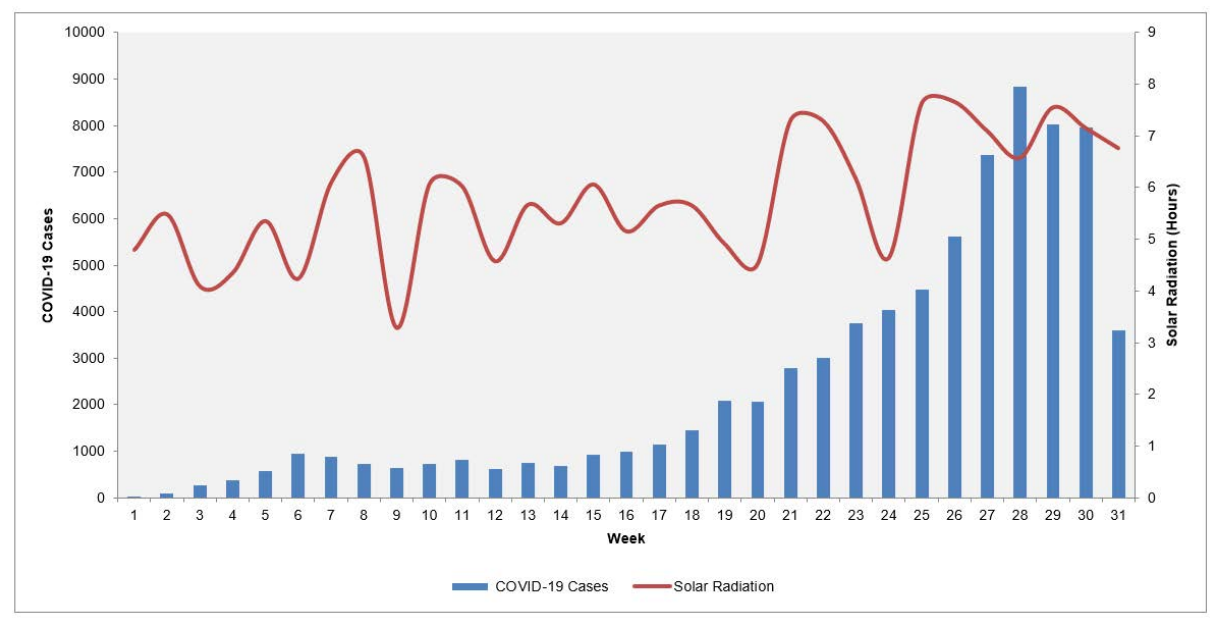

Figure.1 Duration of Solar Radiation Exposure and COVID-19 Cases by Week in Jakarta ${ }^{10,11}$ 

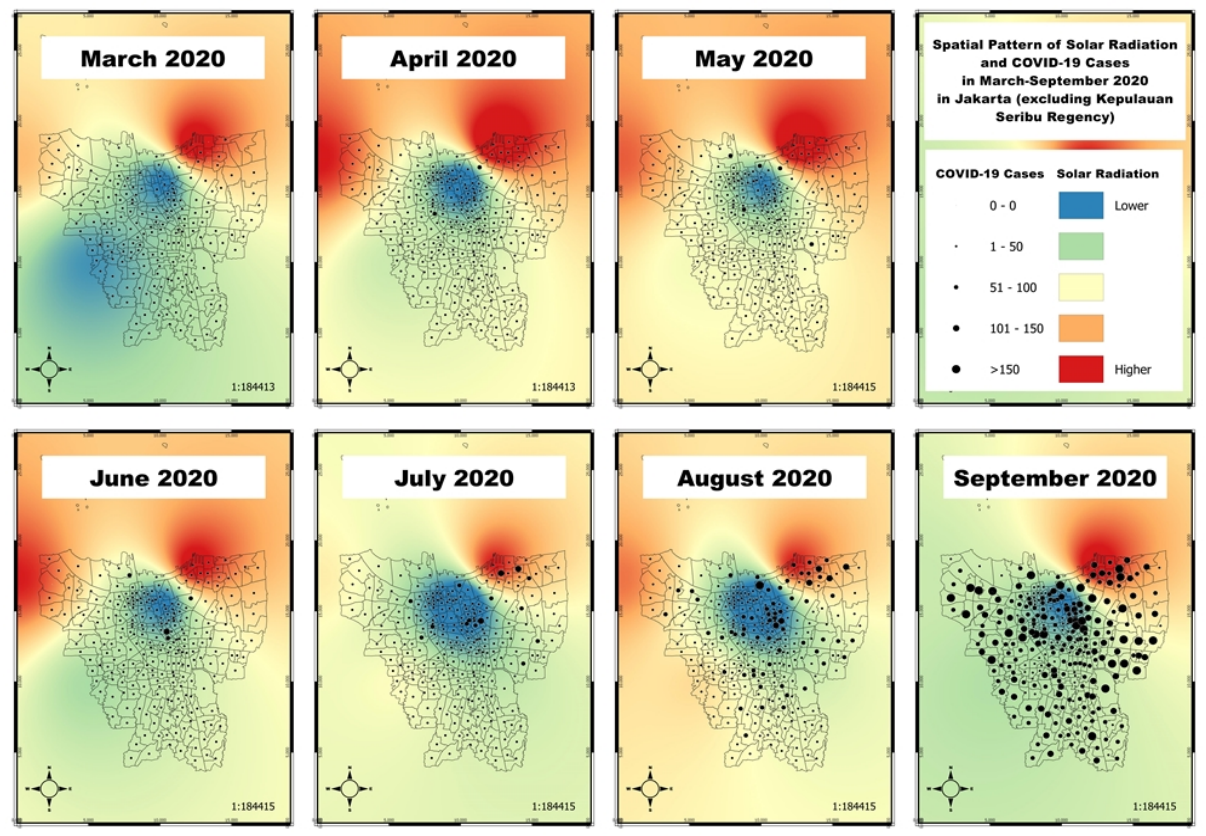

Figure 2. Spatial Patterns between Duration of Solar Radiation Exposure with COVID-19 Cases in March-September 202010,12

\section{Spatial Analysis on Relationship}

The spatial analysis by urban villages was shown by a map overlay of the COVID-19 cases per urban village. This was done with a map of the variable duration of solar radiation exposure in Jakarta as the result of interpolation from weather observation stations. The variable duration was described by color gradation and the cases were represented by a dot symbol. Furthermore, interpolation was conducted to predict the relationship of solar radiation exposure with cases in each urban village.

In this spatial analysis, besides making a high-low comparison of the variable duration on the size of cases, it also showed the movement pattern from March to September 2020. There were incomplete case data per village in Jakarta, which was only obtained from March 25, 2020. This affected the pattern of case distribution in March, which tended to be evenly distributed and were in a low category.

The spatial pattern of solar radiation exposure in each month was relatively the same. Also, it was high in the Northeastern area of Jakarta including the villages of Tanjung Priok, Kebon Bawang, Koja, Lagoa, Kali Baru, Rawabadak Utara, Rawabadak Selatan, Warakas, Papanggo, Tugu Utara, Semper Barat, and Cilincing. Meanwhile, solar radiation exposure was happening in almost all areas of the southern part of Jakarta, which included urban villages in South and East Jakarta. Low radiation exposure happened in almost all areas of the Jakarta center, which included the villages of Pasar Baru, Kemayoran, Senen, Gambir, Kebon Kelapa, and the surrounding. However, it can be seen that sub-districts with high solar radiation exposure tended to experience an earlier increase in cases compared to areas with moderate and low. There was also a fairly high spike in cases in July covering Kebon Bawang (101 cases) and Lagoa (101 cases), and in August which included Lagoa (144 cases), Cilincing (131 cases), Semper Barat (109 cases), Rawabadak Selatan (105 cases) compared to other villages in the vicinity.

\section{Discussion}

The average radiation exposure from March to September 2020 tended to fluctuate, in a range of 3.29 to 7.66 hours. The correlation analysis between the duration of radiation exposure and COVID-19 cases in Jakarta showed a significant, direct, and strong relationship. ${ }^{13}$ This means the higher the radiation exposure, the more the cases. Gupta et al. (2020) in India, showed a significant relationship with a positive correlation between solar radiation exposure and COVID-19. In other words, the higher the radiation exposure, the higher the cases. ${ }^{14}$

There are differences in the results of several studies showing that solar radiation exposure plays a role in the inactivation process of SARS-CoV-2, $6,7,15$ An epidemiological study by Rosario et al. (2020) examined the relationship of solar radiation exposure with COVID-19 cases in Rio de Janeiro. It was stated that solar radiation exposure showed a strong negative correlation with the cases, in other words, high radiation suppressed the virus spread. ${ }^{16}$

Various arguments can be put forward for a unidirectional relationship between radiation exposure and COVID-19 cases in this study, one of which is the hypothesis that people are more vulnerable. This happens when they violate the call to 
stay at home and the sun is shining. ${ }^{17}$ Due to solar radiation exposure conditions that require a certain time in the virus inactivation on different media, the transmission process may take place before inactivation is achieved. 8 Based on a survey by the Central Statistics Agency in September 2020, it was shown that around $26.46 \%$ of the population still did not correctly implement health protocols when outside the house. This condition made the virus transmission more uncontrollable. 18

Based on a graphic analysis, the fluctuations in the duration of solar radiation exposure tended to show a unidirectional relationship with COVID-19 cases. The spatial map overlay also showed that urban villages with high solar radiation exposure tended to increase in cases earlier than those with moderate and low. This strengthened the significance of radiation exposure influence in increasing the number of cases in Jakarta.

\section{Conclusion}

There is a strong and significant relationship between solar radiation exposure and COVID-19 cases $(r=$ $0.666 ; p=0.000)$. Furthermore, the graphic analysis showed a unidirectional relationship pattern between radiation exposure and the cases. These results are reinforced by an overlay spatial map showing that urban villages with high solar radiation exposure tend to experience an increase in cases earlier than areas with moderate and low.

Therefore, tightening of health protocols, maximum capacity, and rules for operating hours should be implemented in crowded places, especially coastal areas. This can be a consideration for the Jakarta Provincial Health Office in strengthening more specific prevention and control programs according to the risk level of each region.

\footnotetext{
Abbreviations

BMKG: Badan Meteorologi, Klimatologi, dan Geofisika (Meteorology, Climatology, and Geophysics Agency); CFR: Case Fatality Rate; COVID-19: Coronavirus Disease 2019; QGIS: Quantum Geographic Information System; SARS-CoV-2: Severe Acute Respiratory Syndrome Coronavirus 2; SPSS: Statistical Product and Service Solutions; UV: Ultraviolet.
}

\section{Ethics Approval and Consent to Participate}

This study was approved by the Research and Community Engagement Ethical Committee, Faculty of Public Health, Universitas Indonesia, No. 210/UN2.F10.D11/PPM.00.02/2021.

\section{Competing Interest}

The authors declare that there is no competing interest.

\section{Availability of Data and Materials}

Data on COVID-19 cases are available on the Jakarta Provincial Health Office at https://corona.jakarta.go.id/id. Furthermore, data on the du- ration of solar radiation exposure can be accessed through the website of Meteorology, Climatology, and Geophysics Agency at https://dataon-line.bmkg.go.id/home. The base map for Jakarta is available on the GADM Maps and website at https:// gadm.org/. In addition, coordinate data for weather monitoring stations can be accessed via https://www.gps-latitudelongitude.com/.

\section{Authors' Contribution}

YAS contributed substantially to the concept, work design, data analysis, interpretation, and drafting of the manuscript. DS made critical revisions of important intellectual content, raised funding, and finalized approval of the version to be published.

\section{Acknowledgment}

The authors are grateful to the Indonesian Ministry of Research and Technology for financial support in contract No. NKB-474/UN2.RST/HKP.05.00/2020.

\section{References}

1. Kementerian Kesehatan Republik Indonesia. Pedoman pencegahan dan pengendalian coronavirus disease (COVID-19). 5th ed. Aziza L, Aqmarina A, Ihsan M, editors. Kementerian Kesehatan RI. Jakarta: Kementerian Kesehatan RI. 2020. 1-214 p.

2. World Health Organization. Coronavirus disease 2019 (COVID-19): Situation report; 2020.

3. Gugus Tugas Percepatan Penanganan COVID-19. Situasi virus COVID-19 di Indonesia. Jakarta; 2020.

4. Prayitno J, Admirasari R, Susanto JP, Nugroho R. Tinjauan teknologi inaktivasi virus untuk penanggulangan pandemi COVID-19. J Bioteknol dan Biosains Indones. 2021 [cited 2021 Jul 22];8(1):13754.

5. Herndon J, Hoisington R, Whiteside M. Deadly Ultraviolet UV-C and UV-B penetration to earth's surface: human and environmental health implications. J Geogr Environ Earth Sci Int. 2018 [cited 2021 Jul 24];14(2):1-11.

6. Sloanid A, Cuttsid T, Griffin BD, Kasloff S, Schiffman Z, Chan M, et al. Simulated sunlight decreases the viability of SARS-CoV-2 in mucus. PLoS One. 2021 Jun 10 [cited 2021 Jul 19];16(6):1-10.

7. Rendell R, Khazova M, Higlett M, O'Hagan J. Impact of high solar UV radiant exposures in spring 2020 on SARS-CoV-2 viral inactivation in the UK. Photochem Photobiol. 2021 [cited 2021 Jul 19];97(3):542-8.

8. Ratnesar-Shumate S, Williams G, Green B, Krause M, Holland B, Wood S, et al. Simulated sunlight rapidly inactivates SARS-CoV-2 on surfaces. J Infect Dis. 2020;222(2):214-22.

9. Achmadi UF. Manajemen Penyakit Berbasis Wilayah. Revisi. Depok: Rajawali Pers; 2012. 1-262 p.

10. Badan Meteorologi Klimatologi dan Geofisika. Data iklim Daerah Khusus Ibukota Jakarta bulan Maret-September tahun 2020. Badan Meteorologi, Klimatologi, dan Geofisika; 2020.

11. Dinas Kesehatan Provinsi DKI Jakarta. Positivity rate hasil laboratorium COVID-19; 2020 [cited 2021 Jan 15].

12. Dinas Kesehatan Provinsi DKI Jakarta. Data COVID-19 Provinsi DKI Jakarta; 2020 [cited 2021 Jan 15].

13. Hastono SP. Statistik kesehatan. Jakarta: Rajawali Pers; 2011. 
Kesmas: Jurnal Kesehatan Masyarakat Nasional (National Public Health Journal). 2021; 16 (Special Issue 1): 44-48.

14. Gupta A, Banerjee S, Das S. Significance of geographical factors to the COVID-19 outbreak in India. Model earth Syst Environ. 2020;1-9.

15. Carvalho FRS, Henriques D V., Correia O, Schmalwieser AW.

Potential of solar UV radiation for inactivation of Coronaviridae family estimated from satellite data. Photochem Photobiol. 2021 [cited 2021 Jul 19];97(1):213-20.

16. Rosario DKA, Mutz YS, Bernardes PC, Conte-Junior CA. Relationship between COVID-19 and weather: case study in a tropical country. Int J
Hyg Environ Health. 2020 [cited 2020 Jul 29];229:113587.

17. Menebo MM. Temperature and precipitation associate with COVID19 new daily cases: a correlation study between weather and COVID19 pandemic in Oslo, Norway. Sci Total Environ. 2020 [cited 2020 Jul 29];1-5.

18. Badan Pusat Statistik. Perilaku masyarakat di masa pandemi COVID19. Jakarta: BPS RI; 2020 [cited 2021 Jul 24] p. 1-50. 